\title{
JEJAK ULAMA UZBEKISTAN DI NUSANTARA
}

\author{
Rijal Mumazziq Z \\ Dosen Fakultas Syari'ah, IAI Al - Falah As - Sunniyyah Kencong \\ rijalmz@gmail.com
}

\begin{abstract}
Uzbekistan is one of the most influential countries in the world, especially in Indonesia. Uzbekistan in the field of science in Islam, in Indonesia there is a proverb that reads, "Far in the eye, close to the heart" which means even though far away but will always remember the brothers and kindness of the brothers. the relation between Uzbek scholars and the Archipelago (Indonesia, now), is an interesting thing. On the one hand, very minimal references and data are obstacles. On the other hand, ignoring the role of scholars from Uzbekistan is also an impossible thing. Because, its contribution cannot be underestimated because it has contributed to strengthening the design of da'wah in the archipelago, especially Java. Also all your efforts on the state and social fields.
\end{abstract}

Keywords: Relationship, Uzbekistan Ulama, Indonesian Ulama

\begin{abstract}
ABSTRAK
Uzbekistan adalah salah satu negara yang berpengaruh penting di dunia khususnya di Indonesia. Uzbekistan dalam bidang keilmuan dalam islam, di Indonesia ada peribahasa yang berbunyi, "Jauh di mata, dekat di hati" yang artinya meski jauh tetapi akan selalu ingat kepada saudara-saudara dan kebaikan budi saudara-saudara. relasi antara ulama Uzbekistan dengan Nusantara (Indonesia, kini), merupakan sebuah hal yang menarik. Di satu sisi, referensi dan data yang sangat minim menjadi kendala. Di sisi lain, mengabaikan peranan ulama asal Uzbekistan juga sebuah hal mustahil. Sebab, kontribusinya juga tak bisa dianggap remeh karena telah ikut andil dalam memperkuat rancang bangun dakwah di Nusantara, khususnya Jawa. Juga segenap usaha saudara di atas lapangan ketatanegaraan dan kemasyarakatan.
\end{abstract}

Kata Kunci : Relasi,Ulama Uzbekistan, Ulama Indonesia

\section{PENDAHULUAN}

Membincang Uzbekistan adalah membicarakan rahim yang melahirkan para raksasa di dunia keilmuan Islam. Kota-kotanya, Bukhara, Samarkand, Tirmidz, Khiva, dan Taskhent menjadi kota inkubator yang memfasilitasi pencapaian para jenius di bidangnya. ${ }^{1}$

${ }^{1}$ Sekarang, memasuki kota-kota di atas seolah memasuki menaiki mesin waktu dan berkelana dalam dimensi ruang dan waktu di masa lampau. Bangunan yang megah, arsitektur yang menarik, hingga jejak kesejarahannya menjadikan kota-kota ini magnetik. Hal ini saya cermati dalam catatan perjalanan para sahabat saya, Mas Sunan Ali (2014) dan Mas Arief Fathur Rizki (2019) saat berkunjung ke kota-kota kuno di Uzbekistan. Dalam catatan yang lebih resmi disertai foto-foto menarik, bisa dilacak melalui perjalanan keluarga

FaLASIFA, Vol. 10 Nomor 1 Maret 2019 | 139 


\section{Rijal Mumazziq Z}

Imam Bukhari dan Imam Tirmidzi di bidang hadits, Imam Nasafi dan Imam Zamakhsyari di bidang tafsir, Imam Maturidi dalam kajian teologi, Ibnu Sina dalam bidang kedokteran dan filsafat, Imam Qaffal As-Syasyi al-Kabir dlam keilmuan fiqh Madzhab Syafi'i, Muhammad bin Musa al-Khawarizmi di jalur matematika, hingga Syekh Baha'uddin alBukhari an-Naqsyabandi ${ }^{2}$ yang menjadi peletak dasar tarekat Naqsyabandiyah. Komplit.

Hanya saja, menelusuri riwayat relasi antara ulama Uzbekistan dengan Nusantara (Indonesia, kini), merupakan sebuah hal yang menarik. Di satu sisi, referensi dan data yang sangat minim menjadi kendala. Di sisi lain, mengabaikan peranan ulama asal Uzbekistan juga sebuah hal mustahil. Sebab, kontribusinya juga tak bisa dianggap remeh karena telah ikut andil dalam memperkuat rancang bangun dakwah di Nusantara, khususnya Jawa.

Ada keluarga dai yang memainkan peranan kuat dalam arus besar dakwah. Mereka terdiri dari kakek, anak, dan cucu. Kakeknya, Syekh Jumadil Kubro alias Syekh Najmuddin Kubro atau Syekh Jamaluddin Akbar al-Huseini datang berdakwah terlebih dulu di Nusantara. Kemudian, putranya, Syekh Ibrahim Zainul Akbar alias Syekh Ibrahim AsSamarqandi menyusul ke Jawa setelah mengislamkan Raja Champa dan menikahi putrinya. Langkah ini diikuti oleh adiknya, Syekh Maulana Ishaq yang juga berhasil melakukan Islamisasi terbatas di Blambangan (Banyuwangi).

Di kemudian hari, putra As-Samarqandi, Raden Ali Rahmatullah (Sunan Ampel) dan Ali Murtadlo (Raden Santri) juga mengikuti jejak ayah dan kakeknya berdakwah di Nusantara, khususnya Jawa. Generasi inilah yang memainkan peranan penting dalam Islamisasi di kawasan Nusantara. Sebab, mereka juga mendidik kader-kader dai tangguh yang berperan penting dalam proses dakwah di kawasan Nusantara timur.

Sebelum masuk pada pembahasan kontribusi dan jejak ulama Uzbekistan di Nusantara, terlebih dulu kita petakan beberapa unsur yang saling berkaitan, yaitu Samarkand-Champa-Jawa, sebab penelusuran kita kali ini akan fokus pada nama Syekh Ibrahim As-Samarqandi, yang dilihat dari namanya merupakan ulama asal Samarkand.

\section{Samarkand: Mutiara di Timur}

"Imam dan ulama mengajar umat di masjid, yang bertambah bagaikan jamur di seluruh kota, kubah biru yang mewah berkilauan di antara awan, bagian dalam cemerlang dengan warna emas dan biru kehijauan. Taman bermunculan satu per satu, oasis ketenangan tersebar di daerah perkotaan. Asia menyerahkan musisi,

Kesebelasan Gen Halilintar yang dituangkan dalam buku Uzbekistan Negara Sababat (Jakarta: GenH Media, 2016), yang ditulis Lenggogeni Faruk, atau catatan perjalanan pengelana asal Lumajang, Agustinus Wibowo, dalam "Berkelana ke Negeri-Negeri Stan" yang termuat dalam Garis Batas: Perjalanan Ke Negeri-Negeri Asia Tengah (Jakarta: Gramedia, 2011).

${ }^{2}$ Kondisi dan tradisi perziarahan di makam Imam Baha'uddin An-Naqsyabandi di Bukhara diulas dengan detail oleh Thierry Zarcone, 'Makam Baha' Al-Din Naqsyband di Bukhara (Uzbekistan)", dalam Henri Chambert-Loir dan Claude Guillot (Ed.), Ziarah dan Wali di Dunia Islam (Jakarta: Komunitas Bambu, 2010), 305-316.

140 | FalAsIfA, Vol. 10 Nomor 1 Maret 2019 
seniman dan pengrajin terhebat demi keagungan Samarkand.

Dari Persia, ibukota budaya di benua itu, berdatangan penyair dan perupa, pelukis, ahli kaligrafi, musisi dan arsitek. Suriah mengirim penenun sutra, pembuat kaca, dan pakaian perang. Setelah kejatuhan Delhi, India menyediakan tukang batu, tukang bangunan, dan pemotong batu mulia sementara Asia Kecil memasok pandai perak, pandai besi, dan pembuat tali. Samarkand adalah salah satu kota paling kosmopolitan di seluruh dunia. Di dalam warga muslim, terdapat orang Turki, Arab, dan Moor. Orang Kristen diwakili oleh Yunani Ortodoks, Armenia, Katolik, Jacobite, dan Nestorian, disertai penghambaan penganut Hindu dan Majusi. Samarkand menjadi wadah aneka ragam, bahasa, agama, dan warna kulit, penerapan kemegahan kerajaan dan tindakan pengabdian oleh seorang lelaki, dengan cinta yang abadi.” (Justin Marozzi). ${ }^{3}$

Demikian Justin Marozzi, wartawan, sejarawan dan penulis perjalanan asal Inggris melukiskan kondisi Samarkand, tujuh abad silam. Sebuah kota dengan kemajemukan yang unik, menjelang kebangkitan Dinasti Timuriyah yang didirikan Timur Leng, ayah Shah Rukh, kakek Ulugh Beg, si pecinta astronomi. Kondisi ini tentu saja mendorong kemajuan di berbagai bidang: militer, kedokteran, arsitektur, astronomi, hingga kajian-kajian keagamaan. Bahkan, empat ratus tahun setelah Bukhara melahirkan Muhammad bin Ismail, Amirul Mukminin fil Hadits, Samarkand masih mempesona dan menarik hati para pendatang.

Di kota ini pula, Syekh Ibrahim Zainul Akbar alias Ibrahim al-Ghazi ${ }^{4}$ alias Syekh Ibrahim As-Samarqandi berasal. Dalam pelafalan Jawa nama ini disebut dengan istilah Syekh Brahim Asmorokondi, atau Makhdum Asmoro. Babad tanah Jawi menyebutnya Makdum Brahim Asmoro. Beliaulah yang dipercayai sebagai ayah dari Sunan Ampel. ${ }^{5}$

Karena bernama "Ibrahim" maka banyak yang salah paham dan menganggapnya sama dengan Syekh Maulana Malik Ibrahim (Wali Gresik). Padahal keduanya berbeda. Syekh Maulana Malik Ibrahim dipercaya berasal dari kawasan Maghribi (Maroko) dan wafat di Gresik pada 1419 M, sedangkan Syekh Ibrahim As-Samarqandi datang ke Jawa pada pertengahan 1440-an M. Makam Maulana Malik Ibrahim ada di Gresik, sedangkan makam Syekh Ibrahim As-Samarqandi terdapat di Tuban.

Dalam sebuah riwayat, Syekh Ibrahim As-Samarqandi merupakan putra dari Syekh Jamaluddin Akbar al-Husaini, yang dianggap sebagai peletak dasar dakwah Walisongo. Dalam versi referensi lokal, Babad Cirebon, sebagaimana dikutip Agus Sunyoto, ayah Syekh Ibrahim as-Samarkandi disebut bernama Syekh Karnen berasal dari negeri Tulen atau

${ }^{3}$ Justin Marozzi, Timur Leng: Panglima Islam Penakluk Dunia (Jakarta: Serambi, 2013), hlm. 251-252.

${ }^{4}$ Nama Ibrahim al-Ghazi ini berdasarkan catatan dari KH. Bisri Musthofa dalam Tarikh Al-Auliya, versi PDF.

${ }^{5}$ Lihat Agus Sunyoto, Atlas Wali Songo (Depok: Pustaka Iman, 2012), hlm. 82.

FalASIFA, Vol. 10 Nomor 1 Maret 2019 | 141 


\section{Rijal Mumazziq Z}

Tyulen. ${ }^{6}$ Saat ini pulau ini termasuk bagian dari Republik Daghestan.

Hanya saja, dalam referensi lain, seperti Hikajat Hasanoeddin, yang disebut sebagai Syekh Karnen atau Syekh Parmen merupakan ayah dari Sunan Ampel alias Raden Rahmatullah. ${ }^{7}$ Selaras dengan sebutan ini, Hikajat Hasanoeddin menyebut apabila Sunan Ampel alias Raden Rahmat berasal dari Champa, merupakan putra dari ulama besar (pandita agung) dari Tulen yang bernama Syekh Parnen. ${ }^{8}$ Dengan demikian, secara garis besar, baik Syekh Jamaluddin Akbar al-Husaini alias Syekh Jumadil Kubro yang silsilahnya menyambung pada Sayyidina Husein bin Ali bin Abi Thalib ini berasal dari kawasan Asia Tengah, yang kemudian berdakwah ke kawasan Nusantara.

Syekh Jamaluddin Akbar al-Husaini ini juga disebut dengan nama Syekh Jumadil Kubro. Masa hidupnya, menurut KH. Abdurrahman Wahid, sezaman dengan Gajahmada. ${ }^{9}$ Banyak versi terkait tokoh satu ini, demikian pula asal usul dan jejak dakwahnya. Sedangkan KH. Abu Fadhol, Senori, Tuban, dalam Ablal Musamarah fi Hikayat Auliya' al-'Asyrah, menjelaskan apabila Syekh Jumadil Kubro memiliki tiga orang anak: Sayyid Maulana Ishaq (ayah Sunan Giri), Syekh Ibrahim As-Samarqandi, dan Sayyidah Ashfa yang diperistri seorang pangeran kerajaan Rum. ${ }^{10}$ Tak heran jika Muhammad Dhiya Syahab dan Abdullah bin Nuh menilai apabila dari Syekh Ibrahim AsSamarqandi inilah kelak sebagian besar Wali Songo dilahirkan. Mereka adalah Sunan Ampel, Sunan Bonang, Sunan Giri, Sunan Drajat, Sunan Kalijaga, Sunan Kudus, Sunan Muria, dan Sunan Gunung Jati. Penisbatan mereka merujuk kepada tempat tinggal di mana mereka berada. ${ }^{11}$

${ }^{6}$ Kepulauan kecil yang terletak di tepi timur Laut Kaspia, tepatnya di arah Barat Laut Samarkand. Saat ini termasuk bagian dari Republik Daghestan. Lihat Agus Sunyoto, Atlas Walisongo (Jakarta: Pustaka Iiman, 2012), hlm. 73.

${ }^{7}$ Dalam Hikajat Hasanoeddin versi terjemahan Melayu, "Adapun kemudian daripada itu, inilah cerita turun-turunan dari yang bernama Pangeran Ampel Denta, dan bernama Pangeran Rabmat, yang beroleh rahmat daripada Allah ta'ala, dan ia asalnya orang Cempa, dan ayahnya itu asal pandita besar dan negeri Tulen, bernama Syekh Parnen.”, lihat Jan Edel, Hikajat Hasanoeddin (Disertasi: Uttrecht, B. Ten Brink, Meppel, 1938), hlm. 64.

${ }^{8}$ Dalam terjemah Melayu disebut Syekh Pamen, dalam teks asli berbahasa Jawa disebut Syekh Karnen.

9 Abdurrahman Wahid, Membaca Sejarah Nusantara: 25 Kolom Sejarah Gus Dur (Yogyakarta: LKiS, 2010), hlm. 22. Gus Dur bahkan menyebut Syekh Jamaluddin Akbar ini membangun surau yang berdampingan dengan kelenteng di Gunung Kawi, Malang. Jika Gus Dur menyebut beliau semasa dengan Gajahmada, berarti leluhur Walisongo ini hidup pada pertengahan abad XIV, sebab Gajahmada diperkirakan meninggal tahun 1363 M.

${ }^{10}$ KH. Abu Fadhol, Senori, Tuban, dalam Ablal Musamarah fi Hikayat Auliya' al'Asyrah (Tuban: Majelis Ta'lif Wal Khattath, tt.), hlm. 4-5.

${ }^{11}$ Lihat, Muhammad Dhiya Syahab dan Abdullah bin Nuh, "Al-Imam Al-Huhajir: Ahmad bin 'Isa bin Muhammad bin Ali Al-Uraidhi bin Ja'far Ash-Shadiq", dalam Peran

142 | FalASIFA, Vol. 10 Nomor 1 Maret 2019 
Bahkan hingga saat ini, banyak versi yang menyebutkan lokasi makam Syekh Jumadil Kubro. Di pekuburan kuno Troloyo, Mojokerto, ada komplek makam Islam yang di dalamnya terdapat makam beliau. ${ }^{12}$ Demikian pula di Terboyo, Semarang. Bahkan, di Tosora, Wajo, Sulawesi Selatan, juga ada versi makam Syekh Jumadil Kubro. Di lokasi ini, beliau dikenal cerita tutur masyarakat sebagai Imam Towajo' (pemimpin agama masyarakat Wajo). ${ }^{13}$ Bahkan, KH. Abdurrahman Wahid juga pernah berziarah ke makam di Mojokerto dan di Wajo ini. Di manakah makam sebenarnya? Wallahu A'lam, yang pasti salah satu makam ini benar keberadaannya, yang lain merupakan petilasan (atsar) sang tokoh. Hal ini juga menjadi bukti apabila tokoh bersangkutan bukan seorang pendakwah yang pasif, berdiam diri di satu tempat; melainkan menjadi dai nomaden yang berkeliling secara simultan dari satu tempat ke lokasi lainnya.

\section{Champa: Titik Persinggahan Penting}

Sebelum ke Nusantara, mula-mula Syekh Ibrahim As-Samarqandi berdakwah ke Champa. Kerajaan yang terletak di pinggir sungai tersebut merupakan salah satu kerajaan yang cukup maju di abad ke-XIV. Raja Champa menolak masuk Islam, bahkan memerintahkan agar Syekh Ibrahim As-Samarqandi beserta beberapa orang yang masuk Islam dibunuh. Usahanya gagal karena keburu meninggal. Raja baru kemudian diperkenalkan dengan Islam, dan ternyata berkenan. Bahkan, Syekh Ibrahim AsSamarqandi kemudian menikahi Dewi Chandrawulan, putri Raja Champa tersebut. Dari pernikahan ini lahirlah Ali Rahmatullah (SUnan Ampel) dan Ali Murtadla (Raden Santri).

Dalam catatan Agus Sunyoto, relasi Majapahit dan Champa sudah terjalin lebih dari dua abad sebelum pendudukan ibukota Champa oleh Raja Vietnam bernama Le NanhTon pada 1446 dan kejatuhan Majapahit pada 1478 M. Relasi kedua kerajaan ini juga diperkuat adanya ikatan pernikahan antara anak Raja Champa yang bernama Dewi Darawati ${ }^{14}$ dengan Prabu Sri Kertawijaya alias Brawijaya V, Raja Majapahit.

Dakwah Damai Habaib/'Alawiyin di Nusantara (Yogyakarta: Rausyan Fikr Institute, 2013), hlm. 68

${ }^{12}$ Martin van Bruinessen setelah melakukan telaah berdasarkan tradisi babad, berpendapat apabila Syekh Jumadil Kubro merupakan sosok yang sama dengan Syekh Najmuddin Kubro, maupun Syekh Jamaluddin Akbar al-Husaini. Nama Jumadil Kubro, alias Jumadil Kabir, ataupun Jumadil Makbur tersebut dalam beberapa babad. Sedangkan nama Jamaluddin Akbar al-Husaini baru muncul dalam beberapa "revisi" nama dan rekonstruksi silsilah yang dilakukan oleh kaum Alawiyyin dalam beberapa dasawarsa terakhir. Semuanya bersandar pada sosok yang sama, seorang waliyullah, nenek moyang para wali dan ulama Jawa. Lihat selengkapnya, Martin van Brunessen, Kitab Kuning, Pesantren dan Tarekat (Bandung: Mizan, 1993), hlm. 24l-244.

${ }^{13}$ Ahmad Baso, Islamisasi Nusantara (Tangerang Selatan: Pustaka Afid, 2018), hlm. 135.

14 Dewi Darawati yang muslimah ini dikenal dengan nama Putri Cempo. Keberadaan makamnya ada beberapa versi. Satu makam terletak Dusun Unggahan, Desa/Kecamatan Trowulan, Mojokerto. Versi lain, ada di Kebomas, Gresik.

FaLASIFA, Vol. 10 Nomor 1 Maret 2019 | 143 


\section{Rijal Mumazziq Z}

Ketika Champa diserbu Vietnam pada 1446 dan 1471, sebagian penduduknya mengungsi ke pesisir Jawa. Meskipun kondisi politik Majapahit saat itu tidak stabil, namun menimbang relasi harmonis antara Champa dengan Majapahit, maka keberadaan mereka bisa diterima dengan baik.

Relasi Champa dan Majapahit ini termuat dalam pengamatan Marco Polo. Dalam catatan perjalanannya dia menyebut Jawa secara khusus, Du Grant Îlle de Iova (Pulau Besar Jawa) yang termuat dalam laman naskah-manuskrip Les Voyages de Marco Polo karangan pelancong tersohor asal Venesia tersebut. Manuskrip ini terhitung sebagai manuskrip Les Voyages tertua dan langka, ditulis sekitar tahun $1350 \mathrm{M}$ atau sekitar 26 tahunan setelah meninggalnya Marco Polo. Manuskrip ini sekarang tersimpan di Perpustakaan Nasional Swedia.

"Pulau Besar Jawa. Tiba dari Champa, seribu lima ratus mil, anda akan mencapai sebuah pulau dengan ukuran yang sangat besar bernama Jawa, yang menurut laporan beberapa navigator merupakan pulau terbesar di dunia, berupa lingkaran seluas tiga ribu mil. Pulau ini (Jawa) memiliki kekayaan yang sangat besar. Mereka memiliki merica, pala, lengkuas, cubeb (cabai Jawa/ kemukus?), cengkih, dan semua jenis rempah-rempah lainnya. Pulau ini dikunjungi oleh kapal-kapal dan saudagar (pedagang), yang darinya para pemilik (kapal-kapal itu) menghasilkan keuntungan tinggi..15

Titik pijakan-pengamatan melalui Champa itu membuktikan apabila kerajaan ini merupakan salah satu titik terpenting dalam relasi antara kerajaan di kawasan Asia Tenggara pada kurun abad ke XIII hingga dua abad setelahnya. Maka tak heran jika pada saat kejatuhan Champa pada 1471, para penduduknya mengungsi ke Jawa.

Di sini, mereka membawa adat kebiasaan dan berbagai kepercayaan. Misalnya, dalam kehidupan sehari-hari, masyarakat Champa memanggil ibu dengan sebutan "Mak". Mereka memanggil kakak atau yang lebih tua dengan istilah "kakak", dan memanggil adiknya dengan sebutan "Adhy". Termasuk pula kebiasaan memperingati hari kematian, pada hari ke-3, 7, 40, 100 hingga 1000. ${ }^{16}$ Tradisi pengajaran baca tulis al-Qur'an juga menggunakan sistem Persia. ${ }^{17}$

Meskipun pernah diserbu dan kerajaannya runtuh, namun hingga saat ini, komunitas muslim Champa masih ada. Kawasan mereka bernama Kampong Champ. ${ }^{18}$

\footnotetext{
${ }^{15}$ Ahmad Ginanjar Sya'ban, "Deskripsi tentang "Du Grant Îlle de Iava" (Pulau Besar Jawa) dalam laman naskah-manuskrip "Les Voyages de Marco Polo" karangan pelancong tersohor asal Venesia, Marco Polo". Makalah belum dipublikasikan, tertanggal 6 Januari 2016.

${ }^{16}$ Agus Sunyoto, Sunan Ampel Raja Surabaya: Membaca Kembali Dinamika Perjuangan Dakwah Islam di Jawa XIV-XV M (Surabaya: Diantama, 2004), hlm. 49.

${ }^{17}$ Agus Sunyoto, Atlas Walisongo, 126.

18 Pada 2008, Muslim di Kamboja mencapai jumlah 321 ribu jiwa. Mayoritas Muslim di Kamboja adalah Sunni bermazhab Syafi'i yang kebanyakan tinggal di Provinsi Kampong Cham. Provinsi dengan luas wilayah $9.799 \mathrm{~km} 2$ itu ditinggali 1.680.694 jiwa (2008). Muslim Cham yakin garis keturunan mereka terhubung hingga ayah mertua
}

144 | FalAsIfA, Vol. 10 Nomor 1 Maret 2019 
Hanya saja jumlah penganut Islamnya sedikit. Terkepung dominasi umat Budha. Di Siem Reap, salah satu kawasan muslim yang juga menjadi tempat tinggal bangsa Champa, akar kesejarahan muslim Champa masih tampak dari atribut pakaian yang digunakan, keberadaan masjid, guesthouse khusus muslim, restoran halal, dan penggunaan bahasa Melayu sebagai bahasa kedua setelah bahasa Khmer. ${ }^{19}$

Tak hanya itu, jejak pernikahan antara orang Nusantara dengan bangsa Champa masih ada. Anak cucu mereka disebut orang "Yuwi" maupun "Jawi". Inilah di antara sekian alasan mengapa dalam aspek ubudiyah, mereka memiliki kesamaan dengan tradisi Ahlussunnah wal Jama'ah ala NU di tanah air. Misalnya dzikir dengan suara keras dan berjabat tangan setelah shalat, membaca Yasin bersama-sama, dan qunut shubuh. "Memang, muslim Champ dari sisi ubudiyahnya amat mirip dengan tradisi keagamaan Nahdlatul Ulama," kata Ustadz Haji Musa, imam Masjid An-Nikmah di Siem Reap ${ }^{20}$ kepada Heru Susetyo. ${ }^{21}$

Di kawasan yang sekarang terletak di Kamboja ini, jejak Islam memang hanya tersisa sedikit saja, tapi dalam pembahasan mengenai relasi Champa dan Jawa, tentu harus diletakkan dalam konteks 7 abad silam, ketika Champa sudah terjamah Islamisasi, sedangkan dakwah Jawa masih tersendat-sendat.

Karena itu, ketika Syekh Ibrahim As-Samarqandi datang ke Jawa, mula-mula harus dipahami sebagai upaya berdakwah dan menyambung matarantai dakwah yang telah dirintis oleh ayahnya, Syekh Jumadil Kubro. Kedatangan beliau ke Jawa bersama dengan dua orang anak dan kemenakannya serta sejumlah kerabat, dengan tujuan menghadap Raja Majapahit yang menikahi adik istrinya, yaitu Dewi Darawati, putri Raja Champa. Sebelum ke Jawa, rombongan Syekh Ibrahim As-Samarqandi singgah dulu di Palembang untuk memperkenalkan Islam kepada Adipati Palembang, Arya Damar. Setelah Arya Damar menjadi muallaf dan mengganti namanya menjadi Ario Abdillah, maka rombongan ini melanjurtkan perjalanan ke Jawa.

Menurut Agus Sunyoto, berdasarkan dari kronologi waktu, Syekh Ibrahim asSamarqandi diperkirakan datang ke Jawa pada sekitar tahun $1440 \mathrm{M}^{22}$ Ini artinya waktu kedatangan beliau terpaut dua dasawarsa dari waktu wafatnya Syekh Maulana Malik Ibrahim pada tahun 1419 M. Berarti Syekh Ibrahim as-Samarkandi menghabiskan waktu beberapa dasawarsa di pulau Sumatera, setelah itu baru datang ke pulau Jawa. Mereka mendarat di sebelah timur Bandar Tuban, yang disebut Gisik (sekarang disebut Gisikharjo,

Rasulullah SAW, Jahsy bin Ri'ab yang merupakan ayah dari Zainab, salah satu istri Rasulullah. Hal itu dikaitkan dengan arus kedatangan para sahabat di Indo-Cina pada 617618 dari Abyssinia melalui jalur laut. Selengkapnya, https://www.republika.co.id/berita/ dunia-islam/islam-digest/17/05/18/oq52xh313-kampong-cham-rumah-muslim-kamboja

${ }^{19}$ Heru Susetyo, The Journal of A Muslim Traveler: Sebuah Perjalanan Melintasi Asia, Eropa, Amerika dan Australia (Jakarta: Lingkar Pena Kreativa, 2009), hlm. 111

${ }^{20}$ Jarak Siem Reap dengan Pnom Penh kurang lebih 230 KM.

${ }^{21}$ Heru Susetyo, The Joumal of A Muslim Traveler, hlm. 113.

${ }^{22}$ Agus Sunyoto, Atlas Walisongo, hlm. 75.

FalAsifa, Vol. 10 Nomor 1 Maret 2019 | 145 


\section{Rijal Mumazziq Z}

Kecamatan Palang, Kabupaten Tuban).

Pendaratan di Gisik dilakukan sebagai salah satu bentuk kehati-hatian, sebab, Tuban saat itu menjadi pelabuhan internasional Majapahit. ${ }^{23}$ Dengan cara mendarat di tempat yang tidak terlalu ramai inilah, mula-mula Syekh Ibrahim As-Samarqandi berdakwah. Di desa ini pula kemudian beliau wafat. Lantas perjalanan menuju Kutaraja Majapahit dilanjutkan kemenakannya, Abu Hurairah (Raden Burereh) yang mendampingi kedua putra Syekh Ibrahim As-Samarqandi, yaitu Ali Rahmatullah (Sunan Ampel) dan Ali Murtadlo (Raden Santri).

Adapun dalam Sejarah Banten disebutkan apabila Ali Rahmatullah ketika dewasa mendengar peperangan di Jawa. Bersama ketika pandhita (ulama) muda lainnya, yaitu Burereh, Seh Salim, dan satu lagi yang tidak disebutkan namanya, Ali Rahmatullah atau juga disebut Raden Rahmat berangkat ke Jawa. Mereka diterima oleh Raja Majapahit. Setelah keempat orang tadi berangkat ke Jawa, Champa diruntuhkan oleh orang Kafir dari Sanggora. ${ }^{24}$

Kedatangan mereka di wilayah pesisir dan membentuk pemukiman di situ, merupakan bagian dari teknik penyisiran dakwah melalui pinggiran. Islamisasi di pinggiran (pesisir) yang meliputi Tuban, Lamongan, Gresik hingga Surabaya, yang dilakukan para Walisongo merupaka strategi penting yang kemudian membentuk motif yang unik karena mulai ajaran Islam mulai merembes ke pedalaman. Dampaknya, munculnya "borjuasi Islam” di kawasan pedalaman sehingga kelak membentuk pola yang unik dalam jejaring Islam di pedesaan melalui tarekat dan pesantren. ${ }^{25}$

Relasi tarekat dan pesantren tidak bisa dipisahkan. Melalui tarekat, persaudaraan Islam dan ritus ruhaniah diperkuat. Salah satu tarekat yang didirikan ulama Uzbekistan yang memiliki akar kuat di Indonesia adalah tarekat Naqsyabandi. Para mursyid tarekat tersebut kebanyakan juga merupakan ulama pengasuh pesantren. Sedangkan di lembaga pendidikan tradisionalis ini pula kitab-kitab karya ulama Uzbekistan diajarkan.

${ }^{23}$ Dalam catatan Velentijn, sebagaimana dikutip Nor Huda, penduduk yang tinggal di lingkungan tembok kotanya hanya 1000 orang pada tahun 1430 M. Lihat, Nor Huda, Islam Nusantara: Sejarah Sosial Intelektual Islam di Indonesia (Yogyakarta: Arruz, 2013), hlm. 40. Dalam catatan Tome Pires, pengelana Portugis, Tuban semakin pesat di pengujung abad ke 15 itu, "Kota Tuban itu tempat kedudukan raja, perdagangan dan pelayaran tidak seperti Gresik. Keratonnya mewah, dan kotanya, meskipun tidak besar sekali, mempunyai pertahanan yang tangguh. Keluarga rajanya sekalipun agama Islam, sejak pertengahan abad $15 \mathrm{M}$ tetap mengadakan hubungan baik dengan Maharaja Majapahit.” Demikian tulis Pires sebagaimana dikutip HJ, De Graaf dan TH. G. TH. Pigeaud, Kerajaan-Kerajaan Islam Pertama di Jawa (Jakarta: Graffiti Press, 1989), hlm. 165.

${ }^{24}$ Husein Djajadiningrat, Tinjanan Kritis Terhadap Sejarah Banten (Jakarta: Djambatan \& KITLV, 1983), hlm. 24.

${ }^{25}$ Lihat Denys Lombard, Nusa Jawa Silang Budaya: Batas-Batas Pembaratan, Kajian Terpadu (bagian 1: Batas-Batas Pembaratan), terj. Winarsih Partaningratn Arifin (Jakarta: Gramedia, 2005), hlm. xix.

146 | FalASIFA, Vol. 10 Nomor 1 Maret 2019 


\section{Karya Ulama Uzbekistan yang Diajarkan di Nusantara}

\section{Suluk Ngasmara}

Dalam catatan Agus Sunyoto, terdapat sebuah kitab berjudul Suluk Ngasmara atau Suluk Asmara, yang diduga tulisan Syekh Ibrahim As-Samarqandi. PJ. Zoetmulder menjadikan Suluk Ngasmara sebagai salah satu rujukan pembanding dalam mengupas kitab karya Sunan Bonang. Meskipun PJ. Zoetmulder hanya membandingkan dua kitab ini dalam konteks kesusastraan, namun dari aspek genealogis, sesungguhnya membandingkan antara karya kakek dengan cucu, sebab, Sunan Bonang adalah cucu Syekh Ibrahim As-Samarqandi. ${ }^{26}$

\section{Shabih Bukbari}

Di antara karya ulama besar Uzbekistan yang diajarkan di tanah air tentu saja Shahih Bukbari dan Sunan At-Tirmidzi. Ulama Indonesia yang memiliki sanad keilmuan di bidang hadits dan mendapatpan ijazah mengajarkan kitab ini adalah $\mathrm{KH}$. Muhammad Hasyim Asy'ari.

Berikut ini sanad Kitab Shahih Bukhari dari KH. Muhammad Hasyim Asyari melalui jalur Syekh Mahfud At-Tarmasi sampai kepada penulis kitab, yakni Imam Abi Abdillah Muhammad bin Ismail Al-Bukhari yang terdiri dari jalur pertama dan kedua:

\section{Jalur pertama:}

1. KH M. Hasyim Asy'ari

2. Dari Syekh Mahfud Termas.

3. Dari Syekh Muhammad Abu Bakar Syatha Al-Makki.

4. Dari Sayyid Ahmad Zaini Dahlan

5. Dari Syekh Utsman bin Hasan Ad-Dimyathi

6. Dari Syekh Muhammad bin Ali As-Syinwani

7. Dari Syekh Isa bin Ahmad Al-Barawi

8. Dari Syekh Muhammad Ad-Dafri

9. Dari Syekh Salim bin Abdillah Al-Bashri

10. Dari ayahnya: Abdillah bin Salim Al-Bashri

11. Dari Syekh Muhammad bin Alaudin Al-Babili

12. Dari Syekh Salim bin Muhammad As-Sanhuri

13. Dari Najm Muhammad bin Ahmad Al-Ghaytho

14. Dari Syekh Al-Islam Zakariya bin Muhammad Al-Anshari

15. Dari Al-Hafidh Ahmad bin Ali bin Hajar Al-Asqalani

16. Dari Ibrahim bin Ahmad At-Tanukhi

17. Dari Abil Abbas Ahmad bin Thalib Al-Hajar

18. Dari Husain bin Mubarak Az-Zabidi Al-Hambali

19. Dari Abil Waqt Abdil Awwal bin Isa As-Sijzi

20. Dari Abil Hasan Abdul Rahman bin Mudzaffar bin Dawud Ad-Dawudi

21. Dari Abi Muhammad Abdullah bin Ahmad As-Srakhsi

26 Agus Sunyoto, Sunan Ampel Raja Surabaya: Membaca kembali Dinamika Perjuangan Dakwah Islam di Jawa XIV-XV M, hlm. 53.

FalAsifa, Vol. 10 Nomor 1 Maret 2019 | 147 
Rijal Mumazziq Z

22. Dari Abi Abdillah Muhammad bin Yusuf bin Mathar Al-Firabri

23. Dari Penyusunnya (orang yang menghimpun hadits), yakni: Al-Imam AlHafid Al-Hujjah Abi Abdillah Muhammad bin Isma'il bin Ibrahim Al-Bukhari

Jalur kedua:

1. KH Hasyim Asy'ari

2. Dari Syekh Mahfudz Termas

3. Dari Sayyid Husain Al-Habsyi

4. Dari Ayahnya Muhammad Husain Al-Habsyi

5. Dari Umar bin Abdul Karim Al-Attar

6. Dari Sayyid Ali bin Abdil Bar Al-Wina’i

7. Dari Abdil Qadir bin Ahmad bin Muhammad Al-Andalusi

8. Dari Muhammad bin Abdillah Al-Idrisi

9. Dari Al-Quthb Muhammad bin Alauddin An-Nahruwali

10. Dari ayahnya

11. Dari Abil Futuh Ahmad bin Abdillah At-Thawusi

12. Dari Baba Yusuf Al-Hirawi

13. Dari Muhammad bin Syadzikhat Al-Farghani

14. Dai Abi Luqman Yahya bin Ammar Al-Khuttalani

15. Dari Muhammad bin Yusuf Al-Farbary

16. Dari Imam Muhammad bin Ismail Al-Bukhari

Demikianlah sanad Kitab Shahih Bukhari sampai Hadratussyekh KH. M. Hasyim Asyari. ${ }^{27}$ Penguasan mendalam Hadratussyekh atas kajian hadits disaksikan oleh KH. Saifuddin Zuhri ketika berkunjung ke kediaman beliau, di Ponpes Tebuireng Jombang:

"Orang yang pernah melihat sendiri, cara Hadratussyekh membaca Al-Bukhari mengatakan bahwa beliau sebenarnya telah hafal seluruh isi kitab ini. Seolaholah sedang membaca kitab karangannya sendiri!"28

Sedangkan Abubakar Atjeh dalam buku Sejarah Hidup KH. A. Wahid Hasyim (2015) memaparkan sedikit gambaran suasana ngaji pasanan (tradisi mengaji kitab saat Ramadan) di Tebuireng kala Hadratussyekh masih hidup. Menurut dia, pada zaman itu, lumrahnya di Bulan Ramadhan pesantren menjadi sepi, sebab para santri diliburkan untuk diberikan kesempatan pulang ke kampungnya masing-masing. Namun, sebaliknya di Tebuireng, suasana justru bertambah ramai, karena kedatangan oleh para santri yang ingin menghabiskan Ramadhan bersama sang guru tercinta.

${ }^{27}$ Selengkapnya baca Syekh Mahfudz At-Tarmasi, Kifayatul Mustafid li Ma Ala Minal Asanid (Beirut: Damul Basya'imul Islamiyah, 1987). versi PDF.

${ }^{28}$ KH. Saifuddin Zuhri, Guruku Orang-Orang Dari Pesantren (Bandung: AlMaarif, 1974), hlm. 152.

148 | FalASIFA, Vol. 10 Nomor 1 Maret 2019 
"Ia (Hadratussyekh, red) selama bulan puasa memberi kuliah istimewa mengenai ilmu hadits karangan Al-Bukbari dan Muslim. Kedua kitab hadits yang penting ini harus khatam dalam sebulan puasa itu dan oleh karena itu, jadilah bulan ini suatu bulan yang penting bagi kiai-kiai mantan muridnya di seluruh Jawa. Dalam bulan puasa, bekas murid-muridnya yang sudah memimpin pesantren di mana-mana, biasanya memerlukan datang tetirah ke Tebuireng, tidak saja untuk melanjutkan hubungan silaturahmi dengan gurunya, tetapi juga untuk mengikuti seluruh kuliah istimewa mengenai hadits Al-Bukhari dan Muslim guna mengambil berkah atau tabaruk, ${ }^{229}$

Sampai sekarang, tradisi pengajian Kitab Shahih Al-Bukbari di Tebuireng pada bulan Ramadhan masih berjalan. Setelah Hadratusyekh wafat, pengajian ini dilanjutkan oleh menantunya, KH. Idris Kamali, dan santri kinasihnya, KH. Syamsuri Badawi, dan kemudian dilanjutkan Gus Ishom Hadzik, cucu Hadratussyekh. Sempat vakum beberapa tahun, akhirnya dari berbagai pertimbangan ditunjukklah Kiai Habib Ahmad, seorang alumni pondok Tebuireng, yang pernah mendapatkan ijazah kitab ini dari Kiai Syamsuri Badawi untuk melanjutkan tradisi ilmiah tersebut.

Meski saat ini sudah jarang pesantren yang mengajarkan kitab induk seperi Shahih Bukhari, namun saya menemukan fenomena unik di Ponorogo. Di desa Karanggebang, Kecamatan Jetis, ada Kiai Mujib Tarwihi yang mengasuh musala alHasan di samping kediamannya. Beliau secara istiqamah mbalagh kitab Shahih Bukbari selama beberapa tahun. Meskipun yang mengaji hanya puluhan orang, tapi tak mengurangi semangat kiai sepuh tersebut mengajar kitab hadits ini.

KH. Maimoen Zubair, pengasuh PP. al-Anwar, Sarang, Rembang, yang diundang dalam rangka memberikan mauidzah hasanah pada khataman Shabih Bukbari pada 2005, bahkan memuji, "Kalau ada pesantren ngaji Shahih Bukhari, itu sudah biasa. Tapi kalau ada langgar yang masih istiqamah ngaji Shahih Bukbari sampai khatam, ini yang sangat langka."130

Setelah khatam kitab ini, Kiai Mujib melanjutkannya dengan mengajarkan Ithaf Sadat al-Muttaqin sebuah syarah Ihya Ulumiddin karya Sayyid Murtadla Az-Zabidi, meskipun tidak sampai rampung karena terlampau tebal. Di kemudian hari, pengajian hadits dilanjutkan dengan mengaji al-Muwattha-nya Imam Malik dan selesai pada 2016. Ketika saya sowan ke kediaman Kiai Mujib tahun 2018 silam, beliau bercerita jika sedang mengkhatamkan Sunan At-Tirmidzi. Luar biasa! Dengan demikian, beliau bisa disebut di antara sedikit kiai yang mengajarkan dua kitab hadits karya ulama Uzbekistan, yaitu Shahih Bukhari dan Sunan At-Tirmidzi

\section{Bahjatul Ulum Syarh Aqidat al-Ushul}

Bahjatul Ulum Syarah Aqidat al-Ushul merupakan karya ulama besar

${ }^{29}$ H. Abubakar Atjeh, Sejarah hidup KH. A. Wabid Hasyim dan Karangan Tersiar (Jombang: Pustak Tebuireng, 2015), hlm. 105-106.

${ }^{30}$ Rijal Mumazziq Z, "Pakpuh Mujib dan Kitab Besar di Musala Kecil", dalam Kiai Kantong Bolong: Refleksi Kepemimpinan Bangsa (Jakarta: Quanta, 2017), 65-68.

FalAsifa, Vol. 10 Nomor 1 Maret 2019 | 149 


\section{Rijal Mumazziq Z}

Uzbekistan, Abu Laits As-Samarqandi. Di rumah, saya memiliki manuskrip kitab ini yang merupakan peninggalan kakek saya (Mbah Kung). Kitabnya agak kumal, bertuliskan tangan di atas kertas kuno. Saya menduga kakek saya mengaji kitab ini saat belajar di Pondok Pesantren Mojosari, Loceret, Nganjuk, dibawah asuhan KH. Zainuddin, awal tahun 1930-an.

Bahjatul Ulum dan Aqidatul Ushul sama-sama ditulis oleh Syekh Abu Laits AsSamarqandi. Kitab Aqidatul Usbul ini masyhur dengan sebutan Kitab "Enem Bis"31 alias kitab "Enam Basmalah". ${ }^{32}$ Maksudnya, permulaan bab dalam kitab aqidah ini selalu dimulai dengan kalimat Bismalahirrahmanirrahim.

Sebelum populer kitab Aqidatul Awam karya Syekh Ahmad al-Marzuqi, Tijan Ad-Darari-nya Syekh Nawawi al-Bantani, maupun Ummul Barahin-nya Syekh Sanusi, Kitab "Enem Bis" inilah yang dipakai dalam silabus pendidikan di bidang teologi di pesantren Jawa maupun Madura pada abad XIX hingga awal abad XX. Aqidatul Ushul ini disebut dalam Serat Centini dengan istilah Semorokondi, dinisbatkan pada nama penulisnya.

4. Masa-il

Ada sebuah risalah singkat karya Imam Abu Laits As-Samarqandi. Judulnya Masa-il Abi Laits. Rupanya risalah ini dipandang perlu diberi uraian oleh Syekh Nawawi al-Bantani (1813-1897 M). Akhirnya beliau menyusun sebuah kitab praktis yang merupakan syarah atas Masa-il-nya Imam Abu Laits. Judulnya, Qathrul Ghaits $f i$ Syarh Masa-il Abi Laits. Format isi kitab ini dialogis. Ada 17 pertanyaan, sekaligus disiapkan jawabannya oleh Imam Abu Laits. Setiap permasalahan yang ingin diterangkan senantiasa didahului dengan kata Mas-alah: Idza qila laka (apabila kamu ditanya?), fal-jawab (maka jawabannya adalah), disertai dengan jawabannya.

Karena itu, bagi saya relasi antara ulama kelahiran Banten dengan Samarkand ini bersifat akademik. Imam Abu Laits As-Samarqandi seorang faqih bermadzhab Hanafi, sedangkan Syekh Nawawi bermadzhab Syafi'i. Imam Abu Laits wafat pada 983 M, sedangkan Syekh Nawawi wafat satu millennium setelahnya. Karya Imam Abu Laits adalah kitab kesekian yang diberi syarah oleh Syekh Nawawi al-Bantani. Beliau yang terkenal mutafannin (multitalenta) ini, juga masyhur sebagai ulama yang mempermudah berbagai bahasan kitab. Sebab beliau banyak menuliskan syarah atas

${ }^{31}$ Kitab "Enem Bis" ini juga disebut dengan kitab Asmarakandi Jawa. Di dalamnya juga memuat bagian fiqh Madzhab Syafi'i elementer yang ditambahkan penerjemah tak dikenal (Abu Laits As-Samaqandi sendiri merupakan pengikut Madzhab Hanafi). Kitab ini kemudian dikomentari secara lengkap oleh Syekh Nawawi al-Bantani melalui Qatr alGhaits, dan terjemahan Jawa Ahmad Subki Pekalongan berjudul Fath al-Mughits. Dalam beberapa periode belakangan kitab ini juga banyak digunakan di berbagai pesantren. Lihat, Martin van Bruinessen, Kitab Kuning, Pesantren dan Tarekat (Bandung: Mizan, 1993), hlm. 28.

${ }^{32}$ Sarkawi B. Husein, Sejarah Masyarakat Islam di Indonesia (Surabaya: Airlangga Pres, 2017), hlm. 16.

150 | FalAsIfA, Vol. 10 Nomor 1 Maret 2019 
sebuah kitab. Kitab karyanya meliputi berbagai jenis keilmuan: tasawuf, tafsir, fiqh, aqidah, etika rumah tangga dan seterusnya. Jumlahnya lebuh dari 100 karya.

Jika Syekh Nawawi al-Bantani tidak secara langsung berguru kepada Syekh Abu Laits As-Samarqandi, maka Syekh Yasin bin Isa al-Fadani (1916-1990), ulama Makkah keturunan Minangkabau, memiliki sanad yang bersambung kepada ulama Uzbekistan. Nama guru beliau Syekh Abdullah bin Muhammad Niyazi al-Bukhari, seorang ahli hadits. Hanya saja penulis belum menelusuri profil dan kiprah guru Syekh Yasin al-Fadani ini.

\section{Tanbibul Ghafilin}

Ini merupakan kitab karya Imam Abu Laits As-Samarqandi yang paling populer. Kitab Tasawuf ini banyak digunakan dalam pengajian-pengajian resmi di beberapa pesantren, maupun bahan baku ceramah para mubaligh. Tanbihul Ghafilin alias "Peringatan bagi Orang-Orang yang Lalai" disusun dengan secara sistematik, penuh hikmah, banyak ucapan (maqalat) para salafus saleh dan tentu saja disertai dengan banyak hadits. Demikian pupulernya kitab ini, beberapa pondok pesantren bahkan menggunakan nama ini sebagai identitas lembaga pendidikannya.

Imam Abu Laits, yang wafat pada 373 H/983 M memiliki nama lengkap Nashr bin Muhammad bin Ibrahim as-Samarqandi al-Hanafi. Dikenal sebagai ulama produktif. Selain Tanbibul Ghafilin beserta catatan pinggirnya yang berjudul Bustanul Arifin, Imam Abu Laits memiliki karya lain, misalnya Tafsir Babrul Ulum, Aqidatul Ushul, dan sebagainya.

\section{Bung Karno dan Makam Imam Bukhari}

Sahabat saya, Mas Didik Isnanto, yang menjadi koki di KBRI di Tashkent, pernah berziarah ke Makam Imam Bukhari. Saat berziarah ke Makam Amirul Mukminin fil Hadits tersebut dia menggunakan kopiah hitam. Penduduk yang berada di sekitar makam tersenyum sambil meneriakkan nama "Zu Karnu, Zu Karnu, Zu Karnu!"

Ingatan mereka melayang kepada seorang negarawan Indonesia, memakai songkok hitam, berkawan akrab dengan Nikita Khruschev, dan berhasil melobi pemimpin Uni Sovyet tersebut agar memugar kembali makam Imam Bukhari. Keberhasilan Bung Karno melobi pemimpin Uni Sovyet adalah upaya yang terus diabadikan di dalam ingatan kolektif penduduk kota Bukhara yang selama puluhan periode dicengkeram rezim komunis. "Ahmed Zu Kar Nu" demikian lidah masyarakat Uzbekistan melafalkan Sukarno dengan penuh hormat. Bahkan, secara spesial, ketika tahu Mas Didik berasal dari Indonesia, penjaga makam secara istimewa membuka ruang bawah tanah, langsung menuju pusara Imam Bukhari. Padahal, tidak semua peziarah diizinkan masuk ke dalam ruang bawah tanah tersebut. ${ }^{33}$

Sigit Aris Prasetyo, dalam Dunia Dalam Genggaman Bung Karno, mengisahkan detail kunjungan Bung Karno ke Uzbekistan yang berlangsung pada 4 September 1956.

${ }^{33}$ Cerita Mas Didik Isnanto, pria asal Malang, yang sudah bertahun-tahun menjadi koki di KBRI di Tashkent.

FalASIFA, Vol. 10 Nomor 1 Maret 2019 | 151 


\section{Rijal Mumazziq Z}

Di negara tersebut, Bung Karno mengunjungi Tashkent dan Samarkand. Termasuk berziarah ke Makam Imam Bukhari. Rakyat mengelu-elukannya dan menyambutnya dengan meriah, bahkan menghadiahi kuda terbaik. Selama di Uzbekistan, Pemimpin Besar Revolusi tersebut dipandu langsung oleh Shar Rasjidov, salah satu tokoh muslim Uzbekistan yang ditunjuk langsung oleh Presiden Voroshilov. Di negara tersebut, Bung Karno benar-benar dihormati. Tak heran pada saat meninggalkan Tashkent pada 6 September 1956, Bung Karno berpidato:

"Kepada rakyat Uzbekistan, di Indonesia ada peribahasa yang berbunyi, "Jauh di mata, dekat di hati”. Hari ini saya meninggalkan Taskhent, tetapi hati saya akan selalu ingat kepada saudara-saudara dan kebaikan budi saudara-saudara. Juga segenap usaha saudara di atas lapangan ketatanegaraan dan kemasyarakatan. Semua tidak mudah saya lupakan. Karena itu saya meninggalkan Tashkent dengan berseru kepada saudara-saudara selamat tinggal. Selamat bekerja. Hiduplah persahabatan kita. Jauh di mata dekat di hati.”

\section{DAFTAR PUSTAKA}

Agus Sunyoto, Atlas Walisongo

Agus Sunyoto, Sunan Ampel Raja Surabaya: Membaca Kembali Dinamika Perjuangan Dakwah Islam di Jawa XIV-XV M (Surabaya: Diantama, 2004) Agus Sunyoto, Sunan Ampel Raja Surabaya: Membaca kembali Dinamika Perjuangan Dakwah Islam di Jawa XIV-XV M,

Ahmad Baso, Islamisasi Nusantara (Tangerang Selatan: Pustaka Afid, 2018), H. Abubakar Atjeh, Sejarah hidup KH. A. Wabid Hasyim dan Karangan Tersiar (Jombang: Pustak Tebuireng, 2015),

Heru Susetyo, The Joumal of A Muslim Traveler: Sebuah Perjalanan Melintasi Asia, Eropa, Amerika dan Australia (Jakarta: Lingkar Pena Kreativa, 2009), Husein Djajadiningrat, Tinjanan Kritis Terhadap Sejarah Banten (Jakarta: Djambatan \& KITLV, 1983),

Justin Marozzi, Timur Leng: Panglima Islam Penakluk Dunia (Jakarta: Serambi, 2013)

Agus Sunyoto, Atlas Wali Songo (Depok: Pustaka Iman, 2012), hlm. 82 Nama Ibrahim al-Ghazi ini berdasarkan catatan dari KH. Bisri Musthofa dalam Tarikh Al-Auliya, versi PDF

Rijal Mumazziq Z, "Pakpuh Mujib dan Kitab Besar di Musala Kecil", dalam Kiai Kantong Bolong: Refleksi Kepemimpinan Bangsa (Jakarta: Quanta, 2017),

Sarkawi B. Husein, Sejarah Masyarakat Islam di Indonesia (Surabaya: Airlangga Pres, 2017),

Sigit Aris Prasetyo, Dunia Dalam Genggaman Bung Kamo (Tangerang: Imania, 2017), 